\title{
How Is the Effect of Inflation to Interest Rate, Exchange Rate and Indonesia Composite Index?
}

\author{
Temy Setiawan* \\ Bunda Mulia University, Jalan Lodan Raya No. 2; Jakarta 14430 \\ Hary S. Sundoro \\ Bunda Mulia University, Jalan Lodan Raya No. 2; Jakarta 14430
}

\begin{abstract}
This study seeks to test the macroeconomy on the Composite Stock Price Index (CSPI). The modeling of this study uses several macroeconomic related factors, which includes inflation, interest rates, and exchange rates. This research was conducted in Indonesia in the observation period 2014 to 2017 (48 observation data). The data used are secondary data collected through the internet. The data are processed using PLS with path analysis. The results of the study show that only inflation has an effect on interest rates and exchange rates against the CSPI. This shows that amongst the government policies which control the macroeconomy, only the exchange rates affect the CSPI.The novelty of this study is that researches on the testing of the form of mediation for inflation, interest rate and exchange rates for the JCI are still limited, so this one can be used as a reference in testing mediation effects. Keywords: inflation, interest rates, exchange rates and CSPI
\end{abstract}

DOI: $10.7176 /$ RJFA/10-10-08

Publication date:May $31^{\text {st }} 2019$

\section{BACKGROUND}

The development of today's business world with the support of technological advancements has led to rapid investment growth (Arifin, 2014; Mankiw, 2015; Miseman,et al., 2013). Transactions in the capital market are very responsive and volatile (samuelson, 2001; Furman and Stiglitz, 1998). Lo (2016) explains that one of the measures used in assessing capital market reactions is taking into account the value of the composite stock price index (CSPI). The price index reflects the market value of all traded shares transactions. The high volatility of CSPI values shows an unstable market (Daferighe and Charlie, 2012). Even though conditions like this provide capital gains or loss for investors, it is not always profitable. The fast and unstable CSPI volatility is an indicator of the reaction of unfavorable economic conditions for a country. Obviously, the economic condition of a country will be an investment consideration for investors (Arifin, 2014; Abdurehman and Hacilar, 2016; Ayub, et al., 2014). One factor which becomes a measure of changes in CSPI is a country's macroeconomic conditions such as inflation, interest rates and exchange rates (Mankiw, 2009; Bai, 2014; Wijayanti and Sudarmiani, 2017;Taufiq and Kefi, 2010; Tafa, 2015). The macro conditions are generally controlled by the government through monetary and fiscal policies (Murtadho, 2016; Mukhlis, Simanjuntak and Prasetyo, 2018; Putri, 2016; Ruhendi and Arifin, 2003; Sanchez, 2005; Tandelilin, 2010). This research is important to see whether government policies on macroeconomic conditions have an impact on the CSPI, especially in the midst of current Indonesian politics which will hold legislative and executive elections in April 2019 for the next 5 years of leadership.

This study raises the issue of inflation, interest rates and exchange rates against the CSPI. Although it did not test the mediating effect of interest rates and the exchange rates on the effect of inflation on the CSPI, this research is still very limited in Indonesia. Therefore, the development of the model with path analysis becomes an urgency in this study. Thus, this research can contribute theoretically to the development of later research. The benefits for investors are to provide empirical evidence on whether macroeconomic conditions controlled by government policies will affect the JCI as a basis for investment decisions. For the public, they explained the factors which influenced the CSPI for the stock market in Indonesia between 2015 and 2017.

\section{LITERATURE REVIEW}

The stock price index can be used as a representative of individual stock performance, sectoral indices or even a composite index of all shares that have been listed on the capital market (Lo, 2016). Thus, the CSPI which reflects the performance of all shares traded in Indonesia can be used to see the condition of the Indonesian capital market at a certain time period. One of the factors affecting the CSPI is macroeconomic conditions such as economic growth, unemployment, inflation, interest rates, and exchange rates (Mankiw, 2009).

Samuelson and Nordhaus (2001) state that inflation is the tendency of general prices to rise continuously. The existence of inflation shows a decrease in the value of the currency against the value of goods and services. On inflation, the government seeks to guard the monetary policy, one of which is to regulate the interest rates of Bank Indonesia (BI). The real interest ratesare the interest rates based on BI provisions by considering an increase in purchasing power or inflation value (Dornbusch et al, 2011). So, there is a correlation between inflation and interest 
rates.

The exchange rates standard is an indicator of how competitive a country is in terms of trade (Min, 1998). Inflation shows the symptoms of decreasing the value of the currency in the country towards the price of goods and services. Therefore, the fund owner seeks to allocate local currency to foreign currency. This will have an impact on the exchange rates. In addition, exports and imports also affect foreign exchange rates. This study provides empirical evidence of currency exchange rates measured by the exchange rates of the rupiah against the US dollar which will affect the CSPI.

\subsection{Inflation on the CSPI}

The existence of inflation indicates an increase in production prices which causes a high burden on the company. At the same time, people's purchasing power declined. Both of these cause the company's profits to decline. With the decline in company profits, the stock value will also decline. This will affect the CSPI (Modigliani and Cohn, 1979; Tandelilin, 2010). Several other studies have discussed that the performance of the stock market in several countries can also be influenced by inflation, such as in Nigeria (Daferighe and Charlie, 2012), in China (Bai, 2014), and in five ASEAN countries: Indonesia, Malaysia, Thailand, Philippines and Singapore (Miseman et al, 2013).

$\mathrm{H}_{1}$ :Inflation influences the CSPI

\subsection{Inflation on the Interest Rates}

Modigliani (1971) and Mishkin (1977) state that when the interest rates is low, it can create an increase in stock performance. This happens because the low-interest rates can make the investment climate more motivated so that the performance of the capital market will improve which is reflected in the increase in the CSPI. This is in line with the Fisher Effect theory (Mankiw, 2015).

$\mathrm{H}_{2}$ : Inflation influences the Interest Rates

\subsection{Inflation on the ExchnageRates}

Inflation and exchange rates can be interrelated where exchange rates can be weakened when inflation is high (Fetai et al, 2016). The research was conducted in the western Balkans countries which include Albania, Macedonia, and Serbia. Due to the presence of inflation, the purchasing power of the people has dropped. Business investors stopped investing in businesses and sought other alternatives, such as entering the money market. Investors will start speculating in foreign currencies. In Indonesia, investors will hold on to the US dollar that they felt is more stable by releasing the Rupiah. This certainly has an impact on the weakening of the exchange rates of the Rupiah against the US Dollar.

$\mathrm{H}_{3}$ : Inflation influences the ExchangeRates

\subsection{Interest Rates on CSPI}

The influence of interest rates on the performance of the CSPI can also be seen from the theory of transmission mechanism of monetary policy (Mayo et al, 2014). Monetary policy is implemented through the determination of the benchmark interest rates which ultimately has an impact on the performance of the CSPI. The high-interest rates will reduce investor interest in conducting transactions in the capital market, especially for investors with a risk-adverse character. They will tend to save their funds in banks with low risk (free risk investment).

$\mathrm{H}_{4}$ : Interest Rates influences CSPI

\subsection{InterestRates on the Exchange Rates}

The interest rates determined through monetary policy (with governmental intervention) will affect the behavior of investors in the market. High interest rates will keep investors from withdrawing funds from banks and buying foreign currency. This is due to the lower level of risk with safer returns. Furman and Stiglitz (1998) conclude from the results of their research that countries in emerging markets will raise interest rates to protect local currency exchange rates.

$\mathrm{H}_{5}$ : Interest rates influences exchange rates

\subsection{Exchange rates on CSPI}

The Rupiah exchange rates are considered to affect the performance of the CSPI (Krisna, 2013). For countries in emerging markets such as Indonesia, which still expects high imports, the depreciating currency will create its own costs. This has caused upheaval in the CSPI because investors are trying to enter the capital market to obtain capital gains or abnormal returns.

Research on the Rupiah exchange rates is also considered to be an important influence on the performance of the CSPI as proven by Ruhendi and Arifin (2003), and Muharam (2008). The measurement of the exchange rates in this study is based on the middle exchange rates of the Rupiah against the USD where the data has been 
published by Bank Indonesia.

$\mathrm{H}_{6}$ : Exchange rates influences CSPI

Figure 1. Research Framework

H.1

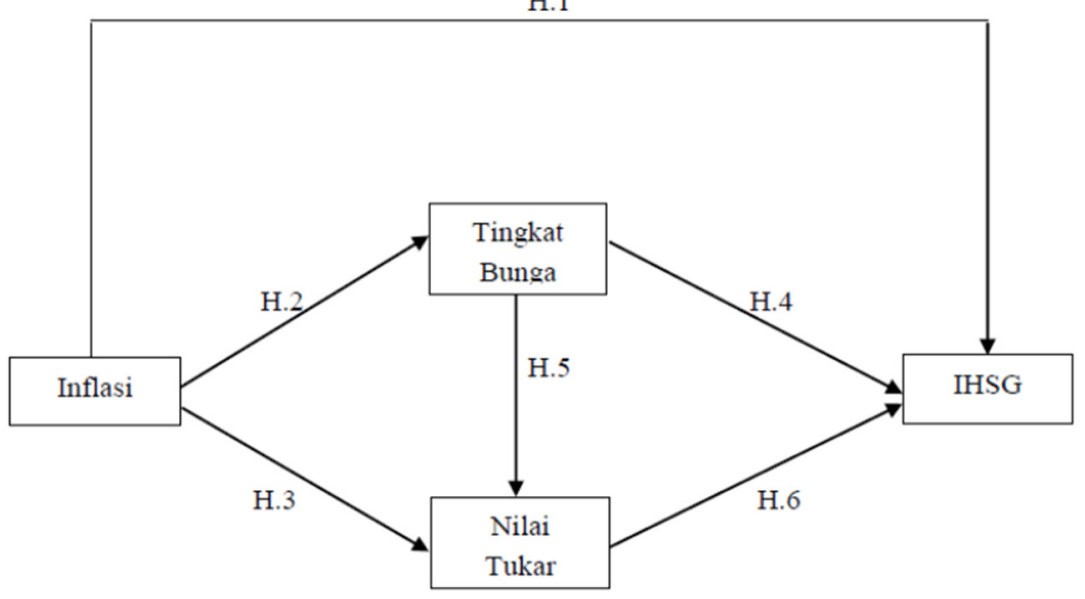

Source: Processed by the Researcher

\section{RESEARCH METHOD}

This is quantitative research using secondary data from the internet. The research is performed through 4 years of observation from 2014-2017 (48 months). The amount of data processed is 48 observation data.

In the measurement of the variables, CSPI data is obtained from Yahoo Finance at the end of the month; 48month data on inflation is obtained from www.bi.go.id while monthly data on Interest rates are obtained from the $\mathrm{BI}$ annual interest rates divided by 12. Exchange rates data is obtained from Yahoo Finance by observing the data on the monthly exchange rates of the rupiah against the US dollar.

Since this research is a form of modeling, the data is analyzed using PLS so that the amount of data can be ignored and no normality and classical assumption is tested (Chin, 1998; Haer, 2007).

\section{RESULTS AND DISCUSSIONS}

Table 1. Descriptive Analysis

\begin{tabular}{|l|c|c|c|}
\hline \multicolumn{1}{|c|}{ Variable } & $\begin{array}{c}\text { Minimum } \\
(\%)\end{array}$ & $\begin{array}{c}\text { Maximum } \\
(\%)\end{array}$ & $\begin{array}{c}\text { Average } \\
(\%)\end{array}$ \\
\hline CSPI (\%) & -0.382 & 0.347 & 0.048 \\
\hline Inflation(\%) & 0.23 & 0.696 & 0.418 \\
\hline Interest Rates(\%) & 0.354 & 0.646 & 0.526 \\
\hline Exchange Rates (Rp) & 11.427 & 14.396 & 12.986 \\
\hline
\end{tabular}

Source: Processed by the Researcher

Table 1 shows the distribution of data for each variable. CSPI data is obtained by observing the daily increase or decrease ratio of closing prices then averaged it in months. The changes of CSPI in average were $0.048 \%$; the highest change was $0.347 \%$ in December 2018, and the lowest change (a decline) was in April 2015 with a value of $-0.382 \%$. Thus the CSPI in Indonesia for 4 years on average experienced an increase each month, although not too significant.

In the inflation variable, information is obtained during the 48 months of the study period. The monthly average inflation of $0.418 \%$ was obtained by dividing the annual inflation by 12 months then reduced by the interest rates to obtain the real inflation value. The lowest monthly real inflation value was $0.23 \%$ and the highest was $0.696 \%$. Indonesia's annual inflation rateswere below $10 \%$ on an annual basis, which puts it in the mild inflation category.

For interest rates, it appears that BI interest rateswere at an average of $0.526 \%$ per month. The lowest point was $0.354 \%$; thiswas because in the period of October 2016 to May 2018 the annual BI rates interest rates did not reach $5 \%$. It was only in the $4.25 \%$ to $4.75 \%$ range per year so that the average value per month (as divided by 12 ) did not reach more than $0.354 \%$. An exception to this can be seen in the period August 2013 to February 2018 which was at an average of $7 \%$ annually (equivalent to $0.6 \%$ monthly).

For the exchange rates of the rupiah against the US dollar, the average was at Rp. 12,986 for every 1 US dollar. The highest point was Rp. 14,396 in May and June 2018 and the lowest point was Rp. 11,427 from February to September 2013. From this data, it appears that the exchange rates of the Rupiah against the US Dollar were in a weakening trend from 2013 to 2018 . 
Figure 2. Outer Model Results

Source: PLS Output

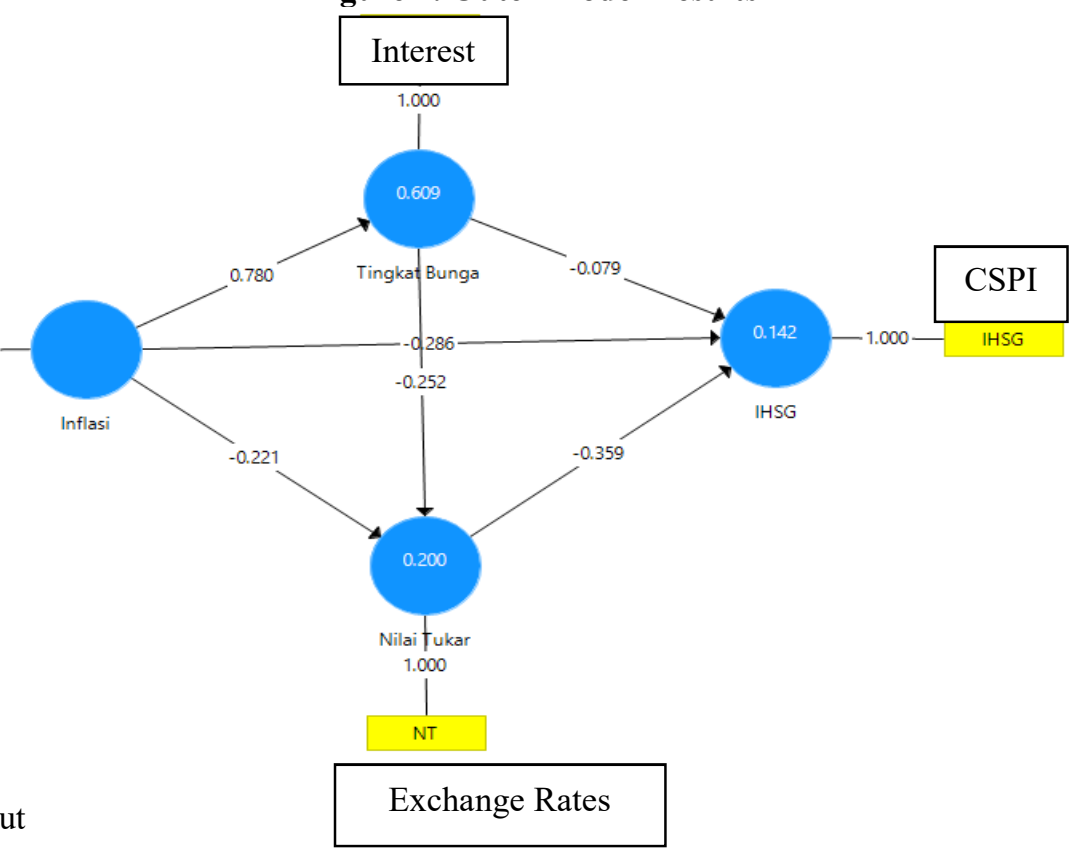

Table 2. $\mathbf{R}^{2}$ Value

\begin{tabular}{|l|c|}
\hline \multicolumn{1}{|c|}{ Variable } & $\%$ \\
\hline CSPI & 0.142 \\
\hline Exchange Rates & 0.200 \\
\hline Interest Rates & 0.609 \\
\hline
\end{tabular}

\section{Source: PLS Output.}

From the PLS output for $\mathrm{R}^{2}$, it can be seen that inflation, interest rates, and exchange rates affect the CSPI by $14.2 \%$ while inflation affects the interest rates by $60.9 \%$. Inflation and interest ratess affect the value of the exchange rates by $20 \%$. From table 2 , it appears that the predictive power of inflation to interest rates is strong while others are moderates (Chin, 1998).

Table 3. Hyppothesis Testing using $p$ value score

\begin{tabular}{|l|l|l|}
\hline \multicolumn{1}{|c|}{ Influence Relationship } & \multicolumn{1}{|c|}{ P-Valuescore* } & \multicolumn{1}{c|}{ Hypothesis results } \\
\hline Inflation on CSPI & 0.183 & Rejected \\
\hline Inflation on Interest Rates & 0.000 & Accepted \\
\hline Inflation on Exchange Rates & 0.420 & Rejected \\
\hline Interest Rates on CSPI & 0.708 & Rejected \\
\hline Interest Rates on Exchange Rates & 0.314 & Rejected \\
\hline Exchange Rateson CSPI & 0.032 & Accepted \\
\hline
\end{tabular}

Source : SPSS Results

* 95\% Significancy

\subsection{The influence of inflation on CSPI}

Table 3 above explains that at the $95 \%$ significance level inflation does not affect the CSPI. However, at the $80 \%$ significance level, inflation will affect the CSPI. This is due to the fact that inflation in Indonesia on a monthly basis was quite low (an average of $0.4 \%$ per month) as shown in table 1 . Since the inflation wais under control for 48 months it did not affect the average CSPI changes.

Inflation causes people's purchasing power to decline so that it is not an option for consumers to consider an investment. Because of that, market stock price fluctuations are not significant because of the weak demand and supply interactions. This causes the value of the CSPI changes to be insignificant. Another explanation is investors in the stock market who affect the CSPI are in general people who have excess funds or who have set it aside for investment so that inflation does not affect the interest and purchasing power of investment. This also explains how inflation has no effect on the CSPI (Liaw, 2013).

\subsection{The influence of inflation on interest rates}

Table 3 shows that the p-value score of the effect of inflation on interest rates shows the number 0.000 (below 0.05 ), which means that there is a significant influence at the $95 \%$ significant level. Inflation encouraged the government to control the BI interest rates policy (Ayub et al, 2014). The higher the inflation, the higher BI interest 
rates to attract money circulation (Berument, 1999). This shows that there was government interference in controlling interest rates due to inflation.

\subsection{The influence of inflation on exchange rates}

Table 3 shows a p-value of 0.420 (above 0.05 ), which means inflation does not influence exchange rates. Inflation is an increase in the average price of goods and services which shows a decrease in the value of a currency. The exchange rate is determined by US dollar demand and supply. Changes in exchange rates are dominated by export and import transactions (international trade), and foreign service transactions. Thus, inflation does not encourage the shift of inventors in holding the domestic currency to foreign currencies for investment reasons. This research is not in line with Wijayanti and Sudarmiani, 2017; Istiqomah, 2013; Marina and Amiruddin, 2016; Istiqamah and Septiana, 2018. This research is in line with Abdurehman and Hacilar (2016) who conducted research in Turkey.

\subsection{The influence of interest rates on CSPI}

Table 3 shows a p-value of below 0.05 for this category. This means that at the $95 \%$ significance level the alternative hypothesis (Ha) is rejected and the null hypothesis (H0) is accepted. The monetary policy of increasing or decreasing interest rates related to the increase or decrease in economic activity did not affect investors in investing. Therefore, it can be said that monetary policy related to interest rates does not affect the CSPI (Kewal, 2012).

The existence of stable interest rates causes investors who are afraid of risks to tend to invest in banks rather than buying shares. Therefore stock trading transactions do not tend to fluctuate which resulted in the CSPI not experiencing drastic changes. If there was a high fluctuation of interest rates, investors will tend to look for alternatives to benefit from the funds they have with investments in the stock market. However, this condition shows poor macroeconomic conditions. For the conditions in Indonesia during the 48 months of observation, BI interest rates increased slowly. This increase, however, does not affect the CSPI since the increase in interest rates was not proportional to inflation. This has led to an increase in interest rates which is more likely to increase consumption rather than investment due to the increase in prices of goods and services.

This research is in line with Kewal (2012) who conducted research from 2007 to 2012 on the effect of interest rates on the CSPI in Indonesia. However, the results of this study are not in line with Manurung (2016) who tested the same variables in 2010 until 2015. Likewise, Taufiq and Kefi (2015) explained that there was an influence of interest rates on the CSPI in 2009 - 2013.

\subsection{The influence of interest rates on exchange rates}

Table 3 shows that hypothesis 5 is rejected because the p-value is higher than 0.05 . Interest rates regulated by the provisions of monetary policy by Bank Indonesia do not affect exchange rates. This is because (1). Interest rates in Indonesia for 48 months were said to be stable so investors who avoid risk tend to be safe in investing. The majority of Indonesian investors are still looking for risk-safe investments; (2). Interest rates do not affect the exchange rate because the exchange rate of the rupiah against the US dollar is more predominantly determined by trade transactions in the form of exports and imports as well as service transactions and not on investments. Therefore, a stable BI interest rate does not affect the exchange rate. This research is not in line with Murthadho (2016) who conducted research on the influence of interest rates on exchange rates in three countries, namely: Indonesia, China and Australia in the observation period of 2012 to 2015. Other studies which were not in line with this study were studied by Belke et al (2004), Sanchez (2005), and Tafa (2015).

\subsection{The influence of exchange rates on CSPI}

Table 3 shows a p-value of below 0.05 which indicates that Ha is accepted and Ho is rejected. This means that the exchange rate affects the CSPI. The weakening of the rupiah exchange rate against the US dollar will make investors to hold back their investments by reducing or not buying investment all together in Indonesia (Putri, 2016; Kewal, 2012; Mukhlis et al, 2018). Because of that, the CSPI declined. Foreign investors prefer to invest in the stock market in a country where the exchange rate against the US dollar is quite stable (Ginting et al, 2016). Contrary to the previous statement, however, Harsono and Worokinasih (2018) explained that the weakening exchange rate would encourage stock investment because investors in the short term expect to get a profit.

Regarding the condition of the exchange rate of the rupiah against the US dollar (table 1), it appears that the exchange rate was on a weakening trend. The weakening of the exchange rate encourages an increase in investment in stocks. A negative correlation occurs. This can be seen in figure 2 which has a coefficient value (-) and in table 1 which shows the volatility of the CSPI changes on average in 48 months.

This research is in line with other studies, namely Manurung (2016) which examined the effect of exchange rates on CSPI on companies listed on the Stock Exchange in 2010 - 2015, and Arifin's research (2014) which supports the results of this study by explaining that the weakening of the exchange rate will affect the increase in CSPI. 


\section{CONCLUSION}

From the discussion section, it appears that the inflation variable which affects the interest rate and the exchange rate has an effect on the CSPI. Other modeling does not provide empirical evidence of the dependence on independent influences. The implications of this study provide a reference for investors that the determinant of the CSPI changes for macroeconomics is the exchange rate of the rupiah against the US dollar. In the event of currency fluctuation, investors can take temporary investment alternatives in the capital market. In addition, risk-fearing investors can use the inflation indicator which will affect BI interest rates through monetary policy. If inflation increases, the government will try to control it with one of the monetary policies by controlling the interest rate. This information can be used as an opportunity to save funds in the bank as an alternative.

Therefore, it can be said that macro policy does not fully affect the CSPI. The role of the legislative and executive bodies through monetary or fiscal policy cannot be reflected in the CSPI because the model's predictive power is only $14.2 \%$ (moderate). The rest of the capital market is influenced by other factors. Therefore, the legislative and executive elections which will occur in Indonesia in the next few periods should not have a significant effect on the CSPI.

My suggestions for other studies which wish to examine other macro variables which might affect the CSPI, they can look at other factors such as unemployment rates, buying and selling transactions for bank Indonesia certificates, or national income. In addition, the character of investors can also be a moderating variable that strengthens the influence of the CSPI. Other researchers can also observe current financial technology factors which can also affect the CSPI. The limitation of this study is that it only conducts quantitative testing with secondary data retrieval. Other studies should try the combination of secondary and primary data through interviews with related parties in the trading of macroeconomic related shares to the CSPI.

\section{References}

Abdurehman, A. A., Hacilar, S. (2016). The Relationship between Exchange Rate and Inflation: An Empirical Study of Turkey. International Journal of Economics and Financial Issues. 6(4), 1454-1459.

Arifin, T. M. (2014). Pengaruh Inflasi, Suku Bunga SBI, Perubahan Kurs, dan Standard \& Poor's 500 terhadap Indeks Harga Saham Gabungan (IHSG). eprints.uny.ac.id/id/eprint/17223.

Ayub, G., Rehman, N. U., Iqbal, M., Zaman, Q., Atif, M. (2014). Relationship between Inflation and Interest Rate: Evidence from Pakistan. Research Journal of Recent Sciences, Vol. 3(4), 51-55, ISSN 2277-2502.

Bai, Z. (2014). Study on the Impact of Inflation on the Stock Market in China. International Journal of Business and Social Science, Vol. 5, No. 7(1).

Belke, A., Geisslreither, K., Gros, D. (2004). On the Relationship between Exchange Rates and Interest Rates: Evidence from the Southern Cone. Cuadernos de Economía. Vol. 41, pp. 35-64.

Berument, H. (1999). The Impact of Inflation Uncertainty on Interest Rates in the UK. Scottish Journal of Political Economy, Vol. 46 No. 2.

Chin, W. W. (1998). The Partial Least Squares Approach for Structural Equation Modeling. G. A. Marcoulides (Ed.), Modern Methods for Business Research (pp.295-236). London: Lawrence Erlbaum Associates.

Daferighe, E., Charlie, S., S. (2012). The Impact of Inflation on Stock Market Performance in Nigeria. American Journal of Social and Management Sciences. doi:10.5251/ajsms.2012.3.2.76.82

Dornbusch, R., Fischer, S., Startz, R. (2011). Macroeconomics. $11^{\text {th }}$ ed. New York (US): McGraw-Hill.

Fetai, B., Koku, P. S., Caushi, A., Fetai, A. (2016). The Relationship between Exchange Rate and Inflation: The Case of Western Balkans Countries. Journal of Business, Economics and Finance, ISSN: 2146-7943.

Furman, J., Stiglitz, J. (1998). Economic Crises: Evidence and Insights from East Asia. Brookings Papers on Economic Activity, Vol. 29, Issue 2, 1-136.

Ginting, M. R. M., Topowijono., Sulasmiyati, S. (2016). Pengaruh Tingkat Suku Bunga, Nilai Tukar dan Inflasi terhadap Harga Saham (Studi pada Sub-Sektor Perbankan di Bursa Efek Indonesia Periode 2011-2015). Jurnal Administrasi Bisnis (JAB). Vol. 35 No. 2.

Hair, J. F. (2007). Multivariate Data Analysis. $6^{\text {th }}$ Edition. New Jersey: Pearson Education Inc.

Harsono, A. R., Worokinasih, S. (2018). Pengaruh Inflasi, Suku Bunga, dan Nilai Tukar Rupiah terhadap Indeks Harga Saham Gabungan (Studi pada Bursa Efek Indonesia Periode 2013-2017). Jurnal Administrasi Bisnis (JAB). Vol. 60 No. 2.

Istiqamah., Septiana, H. A. (2018). Pengaruh Inflasi dan Suku Bunga terhadap Nilai Tukar Rupiah pada Dollar Amerika. Jurnal Spread, Vol. 8 No. 1.

Istiqomah. (2013). Pengaruh Inflasi dan Investasi terhadap Nilai Tukar Rupiah. Signifikan. Vol. 2 No. 1.

Kewal, S. S. (2012). Pengaruh Inflasi, Suku Bunga, Kurs, dan Pertumbuhan PDB Terhadap Indeks Harga Saham Gabungan. Jurnal Economia, Vol. 8 No. 1.

Krisna, A. A. G. A. (2013). Pengaruh Inflasi, Nilai Tukar Rupiah, Suku Bunga SBI pada Indeks Harga Saham Gabungan di BEI. Jurnal Akuntansi Universitas Udayana, 32: 421-435.

Liaw, J. S. (2013). Analisis Pengaruh Tingkat Inflasi, Tingkat Suku Bunga SBI dan Nilai Tukar Rupiah terhadap 
Indeks Harga Saham Gabungan (IHSG) di Bursa Efek Indonesia. eprints.mdp.ac.id/id/eprint/744

Lo, A. W. (2016). What Is an Index?. The Journal of Portfolio Management, 42 (2): 21-36.

Mankiw, G. N. (2009). Macroeconomics. $7^{\text {th }}$ edition. New York: Worth Publishers.

(2015). Macroeconomics. $9^{\text {th }}$ edition. New York: Worth Publishers.

Manurung, R. (2016). Pengaruh Inflasi, Suku Bunga Dan Kurs Terhadap Indeks Harga Saham Gabungan Pada Bursa Efek Indonesia. Jurnal Ekonomi. Vol 19 No 4.

Marina., Amiruddin, K. (2016). Analisis Pengaruh Tingkat Inflasi dan Jumlah Uang Beredar terhadap Nilai Tukar Rupiah di Indonesia. Economics, Social, and Development Studies. Vol. 3 No. 1. ISSN 2407-6635.

Mayo, R., Maskie, G., Pratomo, D. S. (2014). Efektivitas Jalur Kredit dalam Mekanisme Transmisi Kebijakan Moneter di Indonesia. Jurnal Keuangan dan Perbankan, Vol.18: 152-160.

Min, H. G. (1998). Determinants of Emerging Market Bond Spread: Do Economic Fundamentals Matter?. World Bank Policy Research Working Paper, No. 1899: 1-31.

Miseman, M. R., Ismail, F., Ahmad, W., Akit, F. M., Rohana, M., Mahmood, W. M. W. (2013). The Impact of Macroeconomic Forces on the ASEAN Stock Market Movements. World Applied Sciences Journal 23 (Enhancing Emerging Market Competitiveness in the Global Economy). 61-66, 2013 ISSN 1818-4952.

Mishkin, F. (1977), What Depressed the Consumer? The Household Balance Sheet and the 1973-1975 Recession. Brookings Papers on Economic Activity, Vol. 1, pp. 123-164.

Modigliani, F. (1971). Monetary Policy and Consumption: Linkages via Interest Rate and Wealth Effects in the FMP Model, Consumer Spending and Monetary Policy: The Linkages. Federal Reserve Bank of Boston Conference Series, Conference Series. No. 5, June 1971.

Modigliani, F., Cohn, R. A. (1979). Inflation, Rational Valuation and the Market. Financial Analysts Journal, Vol 35: 22-44.

Muharam, H. (2008). Analisis Pengaruh Nilai Tukar Rupiah dan Indeks Dow Jones terhadap Indeks Harga Saham Gabungan. Jurnal Maksi, Volume 8 No 1: 24-42.

Mukhlis, I., Simanjutak, T. H., Prasetyo, T. (2018). The Analysis of the Bank Interest Influence and Exchange Rate Towards Composite Stock Price Index in Indonesia Using Vector Error Correction Model Approach. The First International Research Conference on Economics and Business - Conference Paper. Vol. 2018.

Murtadho, M. (2016). Pengaruh Suku Bunga terhadap Nilai Tukar serta Pengaruhnya terhadap Indeks Harga Saham (Studi Kasus Indonesia, China dan Australia). E-Jurnal Manajemen Kinerja. Vol. 2 No.2 E-ISSN: 2407-7305.

Putri, R. F. A. (2016). Pengaruh Inflasi dan Nilai Tukar terhadap Ekspor Indonesia Komoditi Tekstil dan Elektronika ke Korea Selatan. Jurnal administrasi bisnis. Vol. 35 No. 1.

Ruhendi., Arifin, J. (2003). Dampak Perubahan Kurs Rupiah dan Indeks Saham Dow Jones di New York Stock Exchange terhadap Indeks Harga Saham Gabungan di BEJ. Jurnal Wahana, Vol. 6 hal 45-55.

Samuelson, P., Nordhaus, W. (2001). Economics. $17^{\text {th }}$ ed. New York (US): McGraw-Hill.

Sanchez, M. (2005). The Link between Interest Rates and Exchange Rates, Do Contractionary Depreciations Make a Difference?. Working Paper Series. No. 548.

Tafa, J. (2015). Relationship between Exchange Rates and Interest Rates: Case of Albania. Mediterranean Journal of Social Sciences. Vol. 6 No. 4 ISSN 2039-9340 (print), ISSN 2039-2117 (online).

Tandelilin, E. (2010). Portofolio dan Investasi: Teori dan Aplikasi. Edisi Pertama. Yogyakarta: Kanisius.

Taufiq, M., Kefi, B. S. (2015). Pengaruh Inflasi, BI Rate dan Kurs terhadap Indeks Harga Saham Gabungan. Jurnal Ekonomi Manajemen Akuntansi. Vol. 22 No. 38.

Wijayanti, Y., Sudarmiani. (2017). Pengaruh Tingkat Inflasi terhadap Nilai Tukar Rupiah (Studi pada Bank Indonesia Periode Tahun 2011-2015). Equilibrium. Volume 5, Nomor 1. 